\title{
Medical practitioner's legal regulations in the practice from urban-rural development perspective
}

\author{
Karina Palkova* \\ Rīga Stradinsš University, Faculty of Law, Riga, Latvia
}

\begin{abstract}
The role of medical practitioners in community safety area is huge. Especially huge responsibility medical practitioners have in medical treatment process from the point of view of treatment quality and legal liability. Medical practitioners are professionals regardless of territoriality. The mission and functions they perform do not depend on practice place. The responsibility is equal in both urban and rural level. To protect community safety from the medical practitioners' perspectives they should know their own rights, as well as patient's rights in healthcare. From the particular legal regulations arise duties and responsibilities of medical practitioners, which are described in the paper. The aim of the research is to study legislation that regulates medical practitioner's rights and duties in Latvia. The task of the paper is to study the characteristics of rights of medical practitioners in Latvia and the medical practitioner's knowledge of patients' rights in Latvia. In the research, the author has used general scientific methods such as analysis, synthesis, modelling, comparative method, inductive and deductive method, methods of interpretation of legal norms - grammatical, teleological, historical, as well as empirical method - survey. The paper describes the most important legal regulations in medical practitioner's activity, as well as defines problems and provides potential solutions that are necessary to protect community's safety. The results of the paper show that the regulatory framework exists in the field of healthcare of Latvia. Also in the field of professional activity, legal regulations exist, which govern the professional activity of medical practitioners. They are included in various law sectors (civil rights, labour rights, criminal rights, etc.). Apart from that, there exist a large number of legislative regulations of national level, which govern the professional activities of medical practitioners (special laws and Cabinet Regulations). It should be noted, that the competences of medical practitioners are not consolidated, but stipulated in separate legislative provision for each group of medical practitioners (for a doctor, doctor's assistant, nurse, etc.). The medical practitioner's knowledge of patients' rights is not good enough, especially in rural areas of Latvia.
\end{abstract}

Key words: medical practitioners, medical law.

\section{Introduction}

The modern society is not imaginable without a provision of the healthcare service. The availability of healthcare is a ground of any legal state. Healthcare is a special and quite complicated social institute, which in its creation process has become an internal part of the modern society.

* Corresponding author: karina.palkova@inbox.lv

(C) The Authors, published by EDP Sciences. This is an Open Access article distributed under the terms of the Creative Commons Attribution License 4.0 (http://creativecommons.org/licenses/by/4.0/). 
Currently healthcare and the persons involved therein provide to the society the execution of such tasks as society health provision, individual's right to health and life, etc. For the provision of a successful healthcare process a series of measures should be implemented at national level, including organisation, arrangement and adjustment of public relations in the field of healthcare.

As it is provided in the Conceptual Message of the Cabinet of Ministers "About the Reform of the Healthcare System" from 7 August 2017 [1], the public health indicators in Latvia significantly stay behind other member states of the EU. For example, the number of oncologic patients is 1.3 times larger (3.55\%) than in average in EU (2.7\%), the number of the patients who are first time recognized as disabled twice exceeds the average number in EU, while the people, who evaluate their health as good or very good in Latvia are $-46.2 \%$, average in EU - 67\% [1]. Therefore the abovementioned Conceptual Message included such important healthcare aspects as human resources in healthcare and the main planned activities for their development, provision of medical practitioners in 2016 and 2025, further development of the doctor's profession, as well as medical practitioners' salaries, and the regulatory framework, governing the industry. It should be pointed out that regarding the latter the information provided in the Conceptual Message is insufficient. Nowadays a medical practitioner is the one who must know, understand and must be able to apply legislation, which governs his/her as a specialist's work. The involvement of medical practitioners in the improvements of the healthcare process at various levels, including the socially legal, will allow increasing the efficiency of the healthcare system, as well as the mechanism for the protection of professional activity of medical practitioners.

During last few years, legislation governing the activity of medical practitioners has been actively developed. It can be explained not only with a development of the healthcare system in general, but also with rapid changes in the society's attitude regarding the particular field. The content of the legislation, governing the activity of medical practitioners, in the perfect version is pointed at the improvement of healthcare quality. However due to the hard legislative base and its inaccurate arrangement, the target of the idea might not be achieved. Therefore it is important to systematically arrange (create and systemize) the legislative base, which governs the professional activity of medical practitioners. The professional activity of a medical practitioner is directly related to the legislative provisions determining the industry. For example, the technologies of medical manipulations are related with skills and knowledge of a medical practitioner, while the requirements for their realization always have been determined and governed by legislative provisions [2]. The paper gives insights into the questionnaire results that show the level of the medical practitioner's knowledge in the area of specific legal documents about the patient's rights from urban-rural perspective.

\section{Material and methods}

In the paper, questionnaire results are used, as well as descriptive, analytical and deductioninduction methods. Using these methods, legal acts are analysed as well as recorded opinions of legal scientists, drawn conclusions and made suggestions. The descriptive method is used to describe characteristics of a specific phenomenon of medical practitioner's rights and responsibilities. The method is used to describe the most important of the legal regulations in practice of medical practitioners. There is also used the analytical method, which helps to determine and then evaluate the legal concept or the issue and the content of the legal principles and norms. But deduction-induction methods are used to research current problems from more general to more specific, and opposite - moving from specific observations to broader generalizations and theory. It helps to clarify the outcome of the research. In the 
research, is also used a systematic review, including database search, management and acquisition of relevant literature, and literature review. Applying these methods, legal acts and opinions of legal scientists are analysed and conclusions made.

\section{Results}

In order to clarify the range of the legislative provisions, which govern the professional activity of medical practitioners in the context of protection of rights, a study was carried out and analysis made of the existing legislative provisions of the field. During the study, legislative provisions were identified, which due to the professional activity of medical practitioners regulate the complex of public relations. The legislative provisions by their nature and content are divided into national legislative provisions and international ones (European Justice Portal, Member State Rights - Latvia). From the Articles of the Constitution of the Republic of Latvia, for example, Articles 89, 68, 98, etc., we understand that the international legislative provisions are a part of Latvian legal system [3]. Therefore the activity of medical practitioners is regulated more widely than at national level. In Article 53 of the Vienna Convention on the Law of Treaties, to which Latvia joined on 4 May 1993, it is stated that "the general imperative norm of the international rights is a norm, which is adopted and recognized in the international community of nations as a norm, from which no tolerance is allowed and which might be changed only by a successive general international rule of law, which has the same nature" [4].

As such rules of law, for example, shall be considered the rules, which are stated in the Constitution of the United Nations Organization. In other cases, additional legislation is necessary, for example, the Guidelines of the World Health Organization for Development of National Drug Policies (1988) [5]. This document contains guidelines for the national drug policy. The guidelines cover all aspects which a country needs to know in order to carry out policy effectively, such as legal issues, financial resources, development, and monitoring. As an example should also be mentioned the Convention of the European Council for the Protection of Human Rights and Fundamental Freedoms, to which Latvia joined on 27 June 1997 [6]. The legal provisions of the mentioned convention are the sources of the international rights. Here should be mentioned the Directive 2010/45/EU of the European Parliament and Council from the 7 July 2010 on standards of quality and safety of human organs intended for transplantation [7]. The Directive entered into force on 26 August 2010, and Directive 2011/24/EU of the European Parliament and of the Council from the 9 March 2011 on the application of patients' rights in cross-border healthcare [8]. Consequently the professional activity of medical practitioners is not the issue of the national level only, but it is largely affected by the international aspect, as the principles, stated in the international legislative provisions, are reflected in the legislative provisions of national level. In the study, more attention is paid exactly to national legal sources, which govern the professional activity of medical practitioners and by their nature is an important legal institute in medicine.

The most important rule of law, which governs the professional activity of medical practitioners, is the Constitution [3]. Article 106 of the Constitution states that "everyone has right to freely choose an occupation and workplace according to his/her abilities and qualification..." Therefore the professional activity of medical practitioners shall be supported and protected regardless the institution, public, municipal or private, where the medical practitioner works. Selection of an appropriate form of activity is exclusively in the competence of a medical practitioner. Article 92 of the Constitution states that everyone is allowed to defend his/her rights and legal interests in a fair trial. Everyone shall be considered as innocent, until his/her fault is not adjudged in accordance with law. In case of a groundless 
infringement of rights everyone has right to an appropriate reimbursement. Everyone has right to the lawyer's assistance [3]. The abovementioned is also related to a medical practitioner.

The basic law, which provides the terms for society treatment and a procedure for its provision, is the Medical Treatment Law [9]. In accordance with the Article 2 of the mentioned law, the target of the law is to regulate public relations in medical treatment, in order to provide qualified prevention and diagnostics of diseases or injuries, as well as qualified patient's treatment and rehabilitation and to determine special terms for the legal regulation of medical institution's economic activities [9]. In the Medical Treatment Law there are stipulated ethic issues, medical practitioner's rights and their activity in medical treatment, etc. From the abovementioned arises that the Medical Treatment Law regulates the basic terms related to the healthcare [9].

Also, the Civil Law governs the professional activity of medical practitioners. However, unlike special legal acts, the Civil Law in some ways transforms the institute of the medical practitioners' activity from the social to civil [10] thus providing also the regulation of the medical practitioners' activities in the context of rights of the Civil Law liabilities. Depending on the medical practitioners' activity form medical practitioners may establish, for example:

- Contractual relations,

- Relations with persons, who realize a business in a provision of services of an appropriate field of specialization.

- Relations, which arise from the provision of human basic rights and basic freedom, etc. [10].

At the same time in Article 1635 of the Civil Law it is stated that every infringement of rights, i.e., each individual unauthorised action, which results in a damage (also a moral damage), shall give a right to the victim to demand from an offender a satisfaction to the extent it can be blamed for this action [10]. Therefore, legal relations between a medical practitioner and a patient are regulated. Article 1635 of the Civil Law also states that as a moral damage shall be considered physical or mental suffering, which is infringement of a victim's nonmaterial rights or non-material benefits, caused due to unauthorised action. The amount of remuneration for a moral damage shall be determined by a court according to its discretion, considering the severity and consequences of a damage. While the note provided in the Article points out that an activity here shall be understood in the broadest sense, covering not only an action, but also abstention from it, i.e., inactivity [10]. Article 1644 of the Civil Law states that the person, "who causes damage to other party without an evil intent, if he/she shall be blamed for this damage, comes to negligence."

The negligence may be gross or mild. From the above mentioned one can conclude that in the case of a medical practitioner in their professional activity is allowed negligence, and he/she might come to a civil liability. The medical practitioner's negligence in this case might show up as, for example:

1. A medical practitioner was obligated to take care of a person;

2. A medical practitioner has failed to fulfil or has fulfilled inappropriately the obligation to take care;

3. Due to failure to fulfil the obligation, could foresee a possible damage;

4. Real damage is caused.

Therefore, it can be concluded that a medical practitioner in their professional activity shall be guided by norms of the Civil Law [10].

Latvian Administrative Violations Code, which states the requirements for a medical practitioner in the field of provision of medical services, and control mechanisms of a specific field. Within the Latvian Administrative Violations Code the medical practitioner shall be 
put to trial, which is one of the national compulsory powers and types of responsibility, which is related to impose of administrative penalty [11]. It is a liability for a violation, which harms national or public procedure, property, human rights and stated management procedure. The Latvian Administrative Violations Code determines a series of prohibitions of legally administrative nature. For instance, in accordance with the Article $45 .^{3}$ of the Latvian Administrative Violations Code to a medical practitioner for an illegal disclosure of confidential information obtained during the treatment process shall be applied a fine up to three hundred and fifty euro [11]. At the same time there is stated a liability in it, of which the medical practitioner's obligation arises to operate with the medical private practice, which is registered according to the procedure stipulated by law. A medical practitioner also must be careful with person's data, as for any illegal actions with person's data, including data collection, registration, entry, storage, arrangement, modification, use, transfer, disclosure, blocking or deleting in the Article $204^{7}$ of the Latvian Administrative Violations Code there is provided a liability. A medical practitioner in their professional activity must also observe the principle of equality, i.e., not to allow discrimination, as in Article 204.17 of the Latvian Administrative Violations Code a liability is provided also for the violation of non-discrimination [11].

Additionally should be noted that the professional activity of medical practitioners is guided also by labour rights. For example, the legal provision of the Labour Law regulates relations of medical practitioners as employees and medical institutions as employers. But it shall be applied exclusively on the condition that from the side of an employee or a medical practitioner a work function is realized [12].

The Criminal Law provides the criminal liability of medical practitioners for the offense against human life and health [13]. Part 1 of Article 138 of the Criminal Law states that for the failure to fulfil the medical practitioners' professional obligations or for their negligent fulfilment, if this negligence has caused to a victim a severe body injury or a moderate body injury, the person shall be punished with a deprivation of liberty for a time period up to one year or with a short-time deprivation of liberty, or with a forced labour or a fine. The Article 2 of this law states that for the same offense, if it has caused the victim's infection with a Human Immunodeficiency Virus or B or $\mathrm{C}$ hepatitis virus, or has been a reason for the victim's death, the person shall be punished with a deprivation of liberty for a time period up to five years or with a short-time deprivation of liberty, or with a forced labour or a fine [13]. The regulation of the medical practitioners' professional activity is provided also in Article 136 of the Criminal Law for a forced abortion, in Article 135 of the Criminal Law for the unauthorised abortion, in Article 139 of the Criminal Law for illegal removal of living or deceased person's tissues or organs for the use in medicine, if it is done by a medical practitioner [13].

Article 155 of the Criminal Law provides for deliberately illegal person's placing in psychiatric hospital, Article 154.1 of the Criminal Law for a human trafficking, Article 141 of the Criminal Law for a failure to give a necessary and obvious help to a person, who is in life threatening condition, if a guilty party was aware that they could give it without a severe harm to themselves and other persons, and if the failure to give a help has caused person's death or other severe consequences. The Article 140 determines the medical practitioner's liability for the violation of sanitary hygiene and epidemiological safety regulations [13].

In the practice, common are also problem issues of a legal nature of the medical practitioner's operations with person's data. The mentioned issue is topical also in connection with the fact that on 25 May 2018 in Latvia new Data Protection Regulations of the European Union enter into force [14]. The mentioned data protection terms shall be observed by all enterprises, including medical institutions. 
Considering the abovementioned, special attention shall be paid to Article 145 of the Criminal Law regarding the analysis of legislative regulations, governing the professional activity of medical practitioners. In it, liability for illegal actions with natural person's data is stated, as well as for the influencing the personal data processing manager or operator or data subject, using a violence or threat, or abuse of confidence, or craftily for a purpose to perform illegal actions with a natural person's data. The extent of a medical practitioner's professional activity has been stated also in Article 315 of the Criminal Law, including the medical practitioner's obligation to inform about a gross crime or especially gross crime [13]. In Article 198 of the Criminal Law, in relation with medical practitioners, a prohibition for the acceptance of benefits is determined [13]. It should be noted that until April 2013 the Article 3 of the Criminal Law Convention on Corruption of the European Union stated that the passive bribery is a deliberate action, by which any public official of the country requests or receives, directly or indirectly, any of his/her undue advantage, which is meant for both this official and any other person [15]. In the Article it is stated that the benefit can be meant for both an official and other person. With amendments in the law "On the Criminal Law Convention on Corruption of the European Council", which are made in the law "On the Criminal Law Convention on Corruption of the European Union" (Reporter of the Parliament and Cabinet of Ministers of the Republic of Latvia, 2001, no.3) the mentioned Article was excluded.

The extent of the professional competence of medical practitioners, including regarding a patient, is determined in the Cabinet Regulations. It should be noted that the regulation, stipulated in the Cabinet regulations, has been implemented considering the opinions of social partners and profiled organizations [16]. Cabinet Regulations No.268 from 24 March 2009 "Regulations on the competence of medical practitioners and students who study first or second level professional higher education programs in medicine and the extent of their theoretical and practical knowledge" determine the competences of students and persons, registered in the Medical Person Register, as well as their extent of knowledge of healthcare [17]. Cabinet Regulations No.264 from 23 May 2017 "Regulations on the Classification of Occupations, the basic tasks fulfilling the profession and the basic qualification requirements", the main tasks of medical practitioners are determined [18].

For example, in the Article 160 of these regulations it is determined that professions and appropriate main duties of an individual group "2211 Family (general practice) doctors and doctors" are to examine a patient; to set for a patient diagnostic examinations and analyze their results; to advise a patient on health promotion; to provide a general treatment and its continuity, to provide and receive the information necessary for a patient's treatment from other healthcare specialists, etc. [18]. The Article 167 of the Regulations states that one of the main tasks in the profession of a Nurse is to educate patients [18].

Making the analysis of above stated legislative regulations, author has succeeded to summarize and identify the most significant problems regarding the professional activities of medical practitioners and legislative regulations governing them.

There are a huge number of legal documents that state and provide medical practitioner's regulations in particular field, as well as on patients' and medical practitioner's rights and duties. To find out whether the medical practitioners are informed on the legal documents mentioned above the questionnaire was developed and specific data was collected. The questionnaire offers objective means of collecting information about medical professional's knowledge in the area of patients' rights, attitude to minor patients and relevant behaviour in cities and the countryside of Latvia.

The total number of medical practitioners who participated in the questionnaire is 230 . Of them $83 \%$ - women (or 190) and 17\% - men (or 40) were interviewed. The main place of work of the medical practitioners who participated in the study is Riga, i.e. 62\% (or 143), 
and outside of Riga 38\% (or 87) of respondents. The results of the questionnaire show that the level of medical practitioner's knowledge of patients' rights in Riga and Regions is low and that the medical practitioners in Regions are more tended to professional growth than in Riga. Besides, the competences of medical practitioners are not consolidated, but stipulated in separate legislative provision for each group of medical practitioners (for a doctor, doctor's assistant, nurse, etc.). This does not promote the patient's understanding of the competences of medical practitioners and opposite. In the Medical Practitioner Law the competences of a medical practitioner are not stipulated.

\section{Conclusions}

Making the analysis of the regulations, which govern the professional activity of medical practitioners, it can be concluded that they are based on both national and international legal sources. A big role in the activity of medical practitioners is played by the standards and guidelines in the field of healthcare. Studying the content of the legal regulations, provided in the paper, the following features can be distinguished:

1. Healthcare issue (including the relations between a medical practitioner and a patient) is included in Article 111 of the Constitution. It indicates to the vitality, significance of the tasks, performed by medical practitioners in the cut of international relations;

2. The regulatory framework exists in the field of healthcare of Latvia, and also in a field of professional activity regulation of medical practitioners;

3. Legal regulations, which govern the professional activity of medical practitioners, are included in various law sectors (civil rights, labour rights, criminal rights, etc.);

4. A big number of legislative regulations of national level exist, which govern the professional activities of medical practitioners (special laws and Cabinet Regulations);

5. The competences of medical practitioners are not consolidated, but stipulated in separate legislative provision for each group of medical practitioners (for a doctor, doctor's assistant, nurse, etc.). This does not promote the patient's understanding of the competences of medical practitioners and opposite.

6. The abovementioned inconveniences not only the simplified availability of the information important for the medical practitioner, but does not promote also the patient's understanding of the competences of medical practitioners. In the Medical Practitioner Law the competences of a medical practitioner are not stipulated.

7. The existing legislative regulations are not directed to the interest of medical practitioners to improve their professional knowledge, and to increase their potential with a target to improve the quality of medical services provided to the society.

\section{References}

[1] Conceptual Message of the Cabinet of Ministers "About the Reform of the Healthcare System" (2017). [Accessed 20.09.2018], Available on the Internet: http://www . $\mathrm{vm} . g o v .1 \mathrm{v} / \mathrm{lv} /$ aktualitates/par_veselibas_aprupes_sistemas_reformu/

[2] Злобина О. Ю.,. Солодун Ю. В (2015), Правовое регулирование деятельности врача. Иркутск ИГМУ, p. 4

[3] Constitution of the Republic of Latvia [Accessed 20.03.2018], Available from Internet https: //likumi.lv/doc.php?id=57980

[4] The Vienna Convention on the law of Treaties. [Accessed 20.10.2018], Available on the Internet: https://likumi.lv/ta/lv/starptautiskie-ligumi/id/1 
[5] Guidelines of the World Health Organization for Developing National Drug Policies (1988). [Accessed 20.10.2018], Available on the Internet: http://apps . who.int/medicinedocs/en/d/Js19151en/

[6] Conventions of the European Council for the Protection of Human Rights and Fundamental Freedoms. Available on the Internet: https://likumi.lv/ta/lv/ starptautiskie-ligumi/id/649

[7] Directive 2010/45/EU of the European Parliament and Council from the 7 July 2010 on standards of quality and safety of human organs intended for transplantation. [Accessed 20.03.2018], Available on the European Justice Portal, Member State Rights - Latvia, [Accessed 20.03.2018], Available on the Internet:10 https://e-justice.europa.eu/content_member_state_law-6-lv-lv.do? member $=1$

[8] Directive 2011/24/EU of the European Parliament and of the Council from the 9 March 2011 on the application of patients' rights in cross-border healthcare. [Accessed 20.09.2018], Available on the Internet: https://publications. europa.eu/lv/publication-detail/-/publication/377ab800-836b-4fde85ff-2e4aac7dee94/language-lv

[9] Medical Treatment Law: 12.06.1997 (valid from 01.10.1997). [Accessed 28.11.2018], Available from Internet https://likumi.lv/doc.php?id=44108

[10] Civil Law: 28.01.1937 (valid from 01.09.1992). [Accessed 20.11.2018], Available from Internet: https://likumi.lv/doc.php?id=225418)

[11] Latvian Administrative Violations Code: 07.12.1984 (valid from 01.07.1985) [Accessed 20.03.2018], Available on the Internet: https://likumi.lv/ta/id/ 89648-latvijas-administrativo-parkapumu-kodekss

[12] Labour Law: 20.06.2001 (valid from 01.06.2002). [Accessed 20.10.2018], Available on the Internet: https://likumi.lv/doc .php?id=26019

[13] Criminal Law: 17.06.1998 (valid from 01.04.1999). [Accessed 20.11.2018], Available from Internet: https : / / likumi. Iv/doc . php?id=88966

[14] Regulation (EU) 2016/679 of the European Parliament and of the Council (April 27, 2016) on the protection of individuals with regard to the processing of personal data and on the free movement of such data and repealing Directive 95/46/EC (The General Data Protection Regulation) [Accessed 20.09.2018], Available on the Internet: https://eur-lex.europa.eu/legal-content/LV/TXT/?uri= CELEX\%3A32016R0679

[15] Criminal Law Convention on Corruption. European Treaty Series - No. 173. Strasbourg, 27.I.1999 Available from Internet: https://www.coe.int/en/web/ conventions/full-list/-/conventions/treaty/173

[16] S. Ašnevica- Slokenberga (2015). Medical Rights. Courthouse Agency, p. 192

[17] Cabinet Regulations No.268 from the 24 March 2009 "Regulations on the competence of medical practitioners and students who study first or second level professional higher education programs in medicine and the extent of their theoretical and practical knowledge" determines the competences of students and persons, registered in the Medical Person Register, in healthcare, as well as their extent of knowledge. [Accessed 20.09.2018], Available on the Internet: https://likumi.lv/doc.php?id=190610

[18] Cabinet Regulations No.264 from 23 May 2017 "Regulations on the Classification of Occupations, the basic tasks fulfilling the profession and the basic qualification requirements". [Accessed 20.09.2018], Available on the Internet: https : / / likumi.lv/doc . php?id=291004 